$\begin{array}{cc}\text { ACADEMIA ROMÂNĂ } & \text { Rev. Roum. Chim., } \\ \text { Revue Roumaine de Chimie } & \text { 2019, 64(7), 595-601 } \\ \text { http://web.icf.ro/rrch/ } & \text { DOI: } 10.33224 / \text { rrch.2019.64.7.06 }\end{array}$

\title{
SYNTHESIS AND ANTIMICROBIAL STUDY OF NEW Pt(IV) AND Ru(III) COMPLEXES OF FLUORENYLSPIROHYDANTOINS
}

\author{
Petja MARINOVA,,${ }^{\mathrm{a}, *}$ Marin MARINOV, ${ }^{\mathrm{b}}$ Danail GEORGIEV, ${ }^{\mathrm{b}}$ \\ Maria BECHEVA, ${ }^{\mathrm{c}}$ Plamen PENCHEV ${ }^{\mathrm{a}}$ and Neyko STOYANOV ${ }^{\mathrm{d}}$ \\ ${ }^{a}$ University of Plovdiv, Faculty of Chemistry, 4000 Plovdiv, 24 Tzar Assen St, Bulgaria \\ ${ }^{\mathrm{b}}$ University of Plovdiv, Faculty of Biology, 4000 Plovdiv, 24 Tzar Assen St, Bulgaria \\ ${ }^{\mathrm{b}}$ Agricultural University - Plovdiv, Faculty of Plant Protection and Agroecology, 4000 Plovdiv, 12 Mendeleev Blvd, Bulgaria \\ ${ }^{\circ}$ Medical University - Plovdiv, Medical College - Bulgaria, 4000 Plovdiv, Bulgaria \\ dUniversity of Ruse - Razgrad Branch, Department of Chemistry and Chemical Technology, 7200 Razgrad, 47 Aprilsko Vastanie \\ Blvd, Bulgaria
}

The present work presents a synthesis, characterization and antimicrobial activitiy of new $\mathrm{Pt}(\mathrm{IV})$ and $\mathrm{Ru}(\mathrm{III})$ complexes of (9'-fluorene)-spiro-5-hydantoin (HL1) and (9'-fluorene)spiro-5-(2-thiohydantoin) (HL2). The complexes were investigated by elemental analysis, UV-Vis and IR spectroscopy. The free ligands were studied by UV-Vis, IR, ${ }^{1} \mathrm{H}$ NMR, ${ }^{13} \mathrm{C}$ NMR and Raman spectroscopy. The antimicrobial tests of HL1 showed week bacteriostatic effect against Staphylococcus aureus ATCC 6538. The results for $\left[\mathrm{Pt}(\mathrm{L} 1)_{2}\left(\mathrm{H}_{2} \mathrm{O}\right)_{2}\left(\mathrm{OH}^{-}\right)_{2}\right]$ complex showed a good antimicrobial activity against Escherichia coli ATCC 8739, Bacillus licheniformis ATCC 6633, S. aureus and the absence of such effect on the yeasts. The HL2 and its $\left[\mathrm{Pt}(\mathrm{L} 2)_{2}\left(\mathrm{H}_{2} \mathrm{O}\right)_{2}\left(\mathrm{OH}^{-}\right)_{2}\right]$ and $\left[\mathrm{Ru}(\mathrm{L} 2)_{3}\left(\mathrm{H}_{2} \mathrm{O}\right)_{3}\right]$ complexes do not possess antimicrobial activity against the tested bacteria and yeasts.

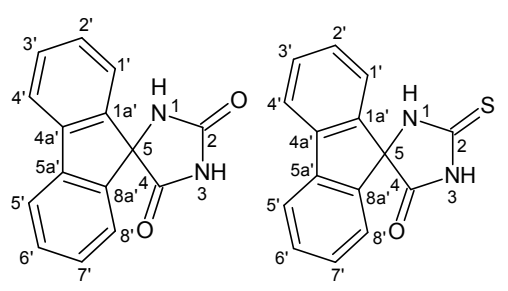

\section{INTRODUCTION}

The hydantoin (imidazolidine) and its derivatives are a class of organic compounds with a wide range of applications in various fields. Several of these (phenytoin, methetoin, mephenythoin, fosphenytoin, norantoin) are well-known anticonvulsive drugs, ${ }^{1}$ whereas others have been suggested to act as antiarrhythmic and antimicrobial agents, skeletal muscle relaxants and nonsteroidal antiandrogens. ${ }^{2}$ Takahashi et al. presented antimutagenicity of 3,5disubstituted 2-thiohydantoins ${ }^{3}$ and 3-allyl-5substituted 2-thiohydantoins derived from allyl isothiocyanate and amino acids in Salmonella assay. ${ }^{4}$ Marton et al. described the synthesis and fungicidal activity of 5-substituted hydantoins and their 2-thio analogues. ${ }^{5}$ Blanc et al. presented the synthesis and immunomodulating and anticancer activity of 5substituted-2-thiohydantoins and 1-amino-2thiohydantoin derivatives. ${ }^{6-8}$ A synthetic procedure and biological activity of 3-aminocycloalkanespiro-5hydantoins were described. ${ }^{9}$ The antiproliferative effect of the compounds was investigated in vitro against a normal cell line and four human tumor cell line (breast, hepatocellular, cervix and colon carcinoma cell line). A series of new diazaspiro bicycle hydantoin derivatives was described and evaluated for cytotoxic effect against human leukemia, K562 (chronic myelogenous leukemia) and CEM (T-cell leukemia). ${ }^{10}$

Especially platinum complexes are in the focus of research since the discovery of the cancerostatica antitumor properties of cisplatin by Rosenberg. ${ }^{11} \mathrm{Pt}(\mathrm{IV})$ complexes have attracted

\footnotetext{
*Corresponding author: petia_marinova@abv.bg
} 
significant attention due to both their kinetic inertness and the resulting possibility of oral administration. Today it its believed that Pt(IV) cancerostatica are just the prodrugs, being reduced to $\mathrm{Pt}(\mathrm{II})$ species in the organism, ${ }^{12}$ although it has been shown that $\mathrm{Pt}(\mathrm{IV})$ complexes can interact with DNA without reduction leading to cancerostatic effects. ${ }^{13,14}$

The biological activity of ruthenium compounds was first discovered in the $1950 \mathrm{~s},{ }^{15}$ and the account of their anticancer activity appeared in the $1960 \mathrm{~s}^{16}$ The first Ru-based anticancer drug candidate in clinical trials was NAMI-A, followed by KP1019 in 2003. Both have successfully completed phase I. This achievement focussed much attention on the medicative properties of Ru compounds. ${ }^{17-21}$ Graf and Lippart published a review of metal-based anticancer drugs and drug candidates, including constructs containing nanomaterials. ${ }^{22}$

Recently, we reported the synthesis of various thioanalogues of cycloalkanespiro-5-hydantoins. ${ }^{23}$ The crystal structures of four cycloalkanespiro-5(2,4-dithiohydantoins) with different size of the saturated ring $^{24}$ and two cycloalkanespiro-5-(2thiohydantoins $)^{25}$ were determined by means of single-crystal X-ray crystallography. Taking into account medical applications of hydantoin derivatives, it is of crucial importance to acquire the knowledge about their interactions with bioavailable metal ions. ${ }^{26}$ In our previous works, we have reported a method for obtaining of 4'-bromo-(9'-fluorene)spiro-5-(2,4-dithiohydantoin) (4-bromo-spiro(fluorene-9,4'-imidazolidine)-2',5'-dithione) ${ }^{27}$ and 3-amino-9'-fluorenespiro-5-hydantoin ${ }^{28}$. In the studies cited above, we have investigated cytotoxic activities of the two compounds on the retinoblastoma cell line WERI-Rb-1 and antibacterial effects towards Gram-positive, Gram-negative bacteria, as well as yeasts $C$. albicans. Recently, we studied the complexation properties of (9'-fluorene)spiro-5-hydantoin and its 2-thio derivative with $\mathrm{Pt}(\mathrm{II})^{29}$ and $\mathrm{Cu}(\mathrm{II})^{30}$, as well as we reported the synthesis and structural characterization of new $\mathrm{Cu}$ (II) and Ni(II) complexes of (9'-fluorene)-spiro-5dithiohydantoin. ${ }^{31}$ The two Pt(II) complexes show significant effects on cancer cell growth compared to their ligands. We also studied the complexation properties of cyclohexanespiro-5-(2,4dithiohydantoin) with $\mathrm{Cu}(\mathrm{II})$ and $\mathrm{Ni}(\mathrm{II}){ }^{32}$ In our previous works, we have presented the synthesis of $\mathrm{N}$-substituted tetralinspiro-5-hydantoins ${ }^{33}$ and the characterization and bioactivities of 3-metyl-9fluorenespiro-5-hydantoin. ${ }^{34}$ Recently, the synthesis of new derivatives of hydrazinecarbothioamides and 1,2,4-triazoles and antimicrobial activity against Gram-positive, Gram-negative bacteria, as well as yeasts Candida albicans have been reported. ${ }^{35}$ The synthesis and cytotoxic activity of new Pt(II), Pt(IV), $\operatorname{Pd}(\mathrm{II})$ and $\operatorname{Pd}(\mathrm{IV})$ complexes with 3-amino- $\alpha$ tetralonespiro-5'-hydantoin ${ }^{36}$ and Pt(II) complexes of 3-aminocyclopentanespiro-5-hydantoin and 3aminocycloheptanespiro-5-hydantoin were investigated. ${ }^{37}$ Although hydantoin and spirohydantoin compounds are studied extensively, there are not many investigations on their complexation properties and antimicrobial activity.

For this reason, the goal of present paper is to report the synthesis and reaction conditions for obtaining of new of $\mathrm{Pt}(\mathrm{IV})$ and $\mathrm{Ru}(\mathrm{III})$ complexes of (9'-fluorene)-spiro-5-hydantoin (HL1) and (9'fluorene)-spiro-5-(2-thiohydantoin) (HL2) with general formulas given in Figure 1, as well as characterization of the obtained complexes by elemental analysis, UV-Vis and IR spectroscopy. The free ligands were described by UV-Vis, IR, ${ }^{1} \mathrm{H}$ NMR, ${ }^{13} \mathrm{C}$ NMR and Raman spectroscopy. The antimicrobial activity of fluorenylspirohydantoin derivatives and their metal complexes against Grampositive bacteria (Staphylococcus aureus ATCC 6538 and Bacillus licheniformis ATCC 6633), Gramnegative bacteria (Escherichia coli ATCC 8739) and the yeasts Candida albicans ATCC 10231 and Sacharomyces serevisiae ATCC 9763 was also studied.

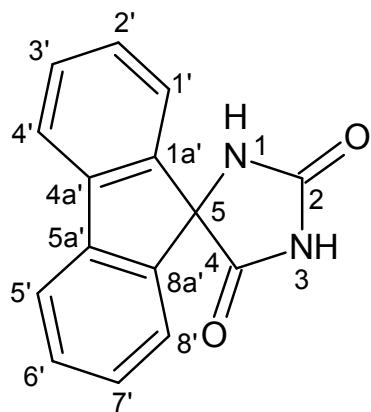

HL1

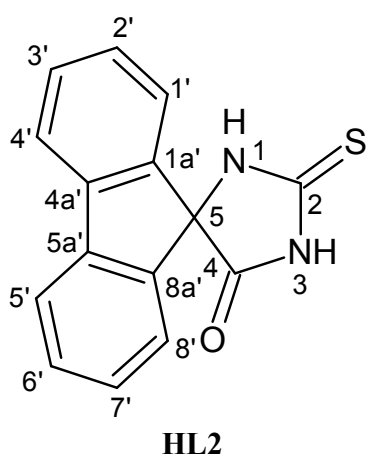

HL2

Figure 1 - Structural formulas of (9'-fluorene)-spiro-5-hydantoin (HL1) and (9'-fluorene)-spiro-5-(2-thiohydantoin) (HL2). 


\section{EXPERIMENTAL}

\section{Instrumentation and methods}

The metal salts $\left(\mathrm{PtCl}_{4}\right.$ and $\mathrm{RuCl}_{3} \cdot \mathrm{H}_{2} \mathrm{O}$ - Sigma-Aldrich or Merck) and the solvents used for synthesis of the complexes were with a p.a. qualification. The two organic ligands HL1 and HL2 were synthesized according to methods described. ${ }^{38,39}$ Electronic spectra were registered on a PerkinElmer Lambda 9 UV/Vis/NIR Spectrophotometer from 200 to $1000 \mathrm{~nm}$. The IR spectra of all compounds were registered in $\mathrm{KBr}$ pellets on a Bruker FT-IR VERTEX 70 spectrometer from 4000 to $400 \mathrm{~cm}^{-1}$ at resolution $2 \mathrm{~cm}^{-1}$ with 25 scans. The Raman spectra of the free ligands were measured on a spectrometer RAM II (Bruker Optics) with a focused laser beam of 20 and $200 \mathrm{~mW}$ power of Nd:YAG laser (1064 nm) from 4000 to $400 \mathrm{~cm}^{-1}$ at resolution $2 \mathrm{~cm}^{-1}$ with 25 scans. The NMR spectra were taken on a Bruker Avance II $+600 \mathrm{MHz}$ NMR spectrometer operating at 600.130 and $150.903 \mathrm{MHz}$ for ${ }^{1} \mathrm{H}$ and ${ }^{13} \mathrm{C}$, respectively, using the standard Bruker software. Chemical shifts were referenced to tetramethylsilane (TMS). Measurements were carried out at ambient temperature.

\section{Syntheses}

\section{Synthesis of Pt(IV) complexes of (9'-fluorene)-spiro-5-hydantoin (HL1) and (9'-fluorene)-spiro-5-(2-thiohydantoin) (HL2)}

The solutions were prepared as follows: $0.0004 \mathrm{~mol}(0.1001 \mathrm{~g})$ of (9'-fluorene)-spiro-5-hydantoin (L1) in $10 \mathrm{~cm}^{3}$ of THF; $0.0004 \mathrm{~mol}(0.1065 \mathrm{~g})$ of (9'-fluorene)-spiro-5-(2thiohydantoin) (L2) in $10 \mathrm{~cm}^{3}$ of THF;

$0.0002 \mathrm{~mol}(0.0674 \mathrm{~g}) \mathrm{PtCl}_{4}$ in $10 \mathrm{~cm}^{3}$ of $\mathrm{H}_{2} \mathrm{O}$;

$0.1 \mathrm{M}$ aqueous solution of $\mathrm{NaOH}$ in a $100 \mathrm{~cm}^{3}$ volumetric flask.

$1 \mathrm{~cm}^{3}$ or $6 \mathrm{~cm}^{3}$ of $0.1 \mathrm{M} \mathrm{NaOH}$ was added slowly to a HL1 or HL2 solutions while stirring at $\mathrm{pH}=10.5$ or 12.5 , respectively. The solution of the metal salt was added dropwise from a burette during stirring with electromagnetic stirrer until precipitation of the formed complexes started after $5 \mathrm{~h}$ or $24 \mathrm{~h}$. The complexes were formed as yellow amorphous precipitates. The precipitates were filtered and washed with $10-20 \mathrm{~cm}^{3} \mathrm{H}_{2} \mathrm{O}$. These were dried over $\mathrm{CaCl}_{2}$ for 2 weeks.

\section{Synthesis of Ru(III) complexes of (9'-fluorene)-spiro-5-hydantoin (HL1) and (9'-fluorene)-spiro-5-(2-thiohydantoin) (HL2)}

The solutions were prepared as follows: $0.0004 \mathrm{~mol}(0.1001 \mathrm{~g})$ of (9'-fluorene)-spiro-5-hydantoin (L1) in $10 \mathrm{~cm}^{3}$ of THF;

$0.0004 \mathrm{~mol}(0.1065 \mathrm{~g})$ of (9'-fluorene)-spiro-5-(2-thiohydantoin) (L2) in $10 \mathrm{~cm}^{3}$ of THF;

$0.0002 \mathrm{~mol}(0.0451 \mathrm{~g}) \mathrm{RuCl}_{3} \cdot \mathrm{H}_{2} \mathrm{O}$ in $10 \mathrm{~cm}^{3}$ of $\mathrm{H}_{2} \mathrm{O}$;

$0.1 \mathrm{M}$ aqueous solution of $\mathrm{NaOH}$ in a $100 \mathrm{~cm}^{3}$ volumetric flask.

While stirring at $\mathrm{pH} 10.5$ one cubic $\mathrm{cm}$ of $0.1 \mathrm{M} \mathrm{NaOH}$ was added slowly to an HL1 or HL2 solution. The solution of metal salt was added dropwise from a burette during stirring with electromagnetic stirrer until precipitation of the formed complexes started after $5 \mathrm{~h}$ or $24 \mathrm{~h}$, respectively. The neutral complexes were formed as brown or black amorphous precipitates. The precipitates were separated by filtration, washed with $10-20 \mathrm{~cm}^{3}$ water and air-dried.

The data of the compounds obtained were as follows: Anal. Calc. for $\left[\mathrm{Pt}(\mathrm{L} 1)_{2}\left(\mathrm{H}_{2} \mathrm{O}\right)_{2}\left(\mathrm{OH}^{-}\right)_{2}\right], \mathrm{C}_{30} \mathrm{H}_{24} \mathrm{~N}_{4} \mathrm{O}_{8} \mathrm{Pt}(\%)$ : C 47.19, H 3.17, N 7.34; found: C 47.50, H 2.96, N 7.48.
Anal. Calc. for [ $\left.\mathrm{Pt}(\mathrm{L} 2)_{2}\left(\mathrm{H}_{2} \mathrm{O}\right)_{2}\left(\mathrm{OH}^{-}\right)_{2}\right], \mathrm{C}_{30} \mathrm{H}_{24} \mathrm{~N}_{4} \mathrm{~S}_{2} \mathrm{O}_{6} \mathrm{Pt}(\%)$ : C 45.28, H 3.04, N 7.04; found: C 45.53, H 3.07, N 7.03.

Anal. Calc. for $\left[\mathrm{Ru}(\mathrm{L} 1)_{3}\left(\mathrm{H}_{2} \mathrm{O}\right)_{3}\right], \mathrm{C}_{45} \mathrm{H}_{33} \mathrm{~N}_{6} \mathrm{O}_{9} \mathrm{Ru}(\%)$ : C 59.86, H, 3.68, N 9.31; found: C 60.02, H 3.56, N 9.49.

Anal. Calc. for $\left[\mathrm{Ru}(\mathrm{L} 2)_{3}\left(\mathrm{H}_{2} \mathrm{O}\right)_{3}\right], \mathrm{C}_{45} \mathrm{H}_{33} \mathrm{~N}_{6} \mathrm{~S}_{3} \mathrm{O}_{6} \mathrm{Ru}(\%)$ : C 56.83, H 3.50, N 8.84; found: C 56.53, H 3.20, N 8.65.

UV (DMSO) HL1: $\lambda_{\max }=215,222,224,231,275 \mathrm{~nm}$.

UV (DMSO) $\left[\mathrm{Pt}(\mathrm{L} 1)_{2}\left(\mathrm{H}_{2} \mathrm{O}\right)_{2}\left(\mathrm{OH}^{-}\right)_{2}\right]: \lambda_{\max }=223,236,276$, $300 \mathrm{~nm}$.

UV (DMSO) $\left[\mathrm{Ru}(\mathrm{L} 1)_{3}\left(\mathrm{H}_{2} \mathrm{O}\right)_{3}\right]: \lambda_{\max }=224,273 \mathrm{~nm}$.

Raman, $v\left(\mathrm{~cm}^{-1}\right) \mathrm{HL} 1: 3073(v \mathrm{CH}), 3041(v \mathrm{CH}), 3012(v \mathrm{CH})$, 1777 (vCO), 1720 (vCO), 1605, 1584, 1486, 1450, 1362, $1351,1299,1230,1154,1115,1084,1023,990,785,736$, $724,684,638,514,445,414$.

${ }^{1} \mathrm{H}$ NMR $\left(600 \mathrm{MHz}, \mathrm{DMSO}-d_{6}\right) \mathrm{HL} 1 \delta_{\mathrm{H}}: 11.26$ (s, NH-3), 8.61 (s, NH-1), 7.89 (d, 4'/5'), 7.51 - 7.47 (m, H-1'/8', H3'/6'), 7.37 (t, H-2'/7').

${ }^{13} \mathrm{C}$ NMR $\left(600 \mathrm{MHz}\right.$, DMSO- $\left.d_{6}\right) \mathrm{HL1} \delta_{\mathrm{C}}: 174.59\left(\mathrm{C}_{4}=\mathrm{O}\right)$, $158.06\left(\mathrm{C}_{2}=\mathrm{O}\right), 143.38\left(\mathrm{C}_{1 \mathrm{a}^{\prime} / 8 \mathrm{a}^{\prime}}\right), 141.12\left(\mathrm{C}_{\left.4 \mathrm{a}^{\prime} / 5 \mathrm{a}^{3}\right), 130.28}\right.$ $\left(\mathrm{CH}_{3^{\prime} / 6^{\prime}}\right), 128.81\left(\mathrm{CH}_{2^{\prime} / 7^{\prime}}\right), 124.02\left(\mathrm{CH}_{1^{\prime} / 8^{\prime}}\right), 121.20\left(\mathrm{CH}_{4^{\prime} / 5^{\prime}}\right)$, $72.84\left(\mathrm{C}_{5}\right)$.

UV (DMSO) HL2: $\lambda_{\max }=216,225,275,300 \mathrm{~nm}$.

$\mathrm{UV}(\mathrm{DMSO})\left[\mathrm{Pt}(\mathrm{L} 2)_{2}\left(\mathrm{H}_{2} \mathrm{O}\right)_{2}\left(\mathrm{OH}^{-}\right)_{2}\right]: \lambda_{\max }=220,231,275 \mathrm{~nm}$.

$\mathrm{UV}$ (DMSO) $\left[\mathrm{Ru}(\mathrm{L} 2)_{3}\left(\mathrm{H}_{2} \mathrm{O}\right)_{3}\right]: \lambda_{\max }=276,285,290$ and $303 \mathrm{~nm}$. Raman $v\left(\mathrm{~cm}^{-1}\right)$ HL2:3067 (vCH), $3050(v \mathrm{CH}), 1728$ (vCO), 1624, 1607, 1486, 1448, 1359, 1296, 1233, 1211, 1157, 1151, $1113,1074,1022,1006,942,786,760,743,726,675,624$, $537,515,475,418$.

${ }^{1} \mathrm{H}$ NMR (600 MHz, DMSO- $\left.d_{6}\right)$ HL2 $\delta_{\mathrm{H}}: 12.36$ (s, NH-3), 10.61 (s, NH-1), 7.90 (d, H-4'/5'), 7.48 (td, H-3'/6'), 7.39 (d, $\left.\mathrm{H}-1^{\prime} / 8^{\prime}\right), 7.36$ (t, H-2'/7').

${ }^{13} \mathrm{C}$ NMR $\left(600 \mathrm{MHz}\right.$, DMSO- $\left.d_{6}\right)$ HL2 $\delta_{\mathrm{C}}: 183.52\left(\mathrm{C}_{4}=\mathrm{O}\right)$, $174.72\left(\mathrm{C}_{2}=\mathrm{S}\right), 141.31\left(\mathrm{C}_{1 \mathrm{a}^{\prime} / 8 \mathrm{a}^{\mathrm{a}}}\right), 140.71\left(\mathrm{C}_{\left.4 \mathrm{a}^{\prime} / 5 \mathrm{a}^{3}\right),}\right), 130.19$ $\left(\mathrm{C}_{3{ }^{\prime} / 6}, \mathrm{H}\right), 128.56\left(\mathrm{C}_{2^{\prime} / 7} \cdot \mathrm{H}\right), 123.68\left(\mathrm{C}_{1 / 8}, \mathrm{H}\right), 120.98\left(\mathrm{C}_{4}{ }^{\prime},{ }^{\prime}, \mathrm{H}\right)$, $74.75\left(\mathrm{C}_{5}\right)$.

\section{Antimicrobial assay}

The microbial cultures were purchased from National Bank of Industrial Microorganisms and Cell Cultures (NBIMCC), Sofia. The antimicrobial effect of the synthesized compounds HL1, HL2 and their Pt(IV) and Ru(III) complexes against Gram-positive bacteria Staphylococcus aureus ATCC 6538 and Bacillus licheniformis ATCC 6633, Gram-negative bacterium Escherichia coli ATCC 8739 and the yeasts Candida albicans ATCC 10231 and Sacharomyces serevisiae ATCC 9763 was studied. The technique used for this investigation was the agar well diffusion method. ${ }^{40}$ The used agar media were Muller-Hinton agar for the tests with bacteria and Sabouraud-decstrose agar for yeast. The wells were filled with solutions $(100 \mu \mathrm{L})$ of the compounds synthesized and, following a 30-min stay at room temperature, the Petri dishes were placed in a thermostat at $37{ }^{\circ} \mathrm{C}$ for $24 \mathrm{~h}$ for bacteria and $28^{\circ} \mathrm{C}$ for $24 \mathrm{~h}$ for yeasts. After cultivation, the diameter of inhibition growth zones around wells was measured in $\mathrm{mm}$, and the results obtained were evaluated as follows: up to $15 \mathrm{~mm}$ - the microbial culture is week sensitive, $15-20 \mathrm{~mm}$ - it is sensitive and over $25 \mathrm{~mm}$ - it is very sensitive to the given synthetic compound at tested concentration. The concentrations $(\mathrm{mg} / \mathrm{mL})$ of compounds HL1, HL2 and their Pt(IV) and Ru(III) complexes in DMSO were as follows: $72.2,32.8$ and $44.1,15.2,32.5,34.5$, respectively. The pure DMSO $(100 \mu \mathrm{L})$ was used as a control. The data on antimicrobial activity are arithmetic average of three measurements. 


\section{RESULTS AND DISCUSSION}

Complexation with $\mathrm{Pt}(\mathrm{IV})$ and $\mathrm{Ru}(\mathrm{III})$ using a metal salts namely $\mathrm{PtCl}_{4}$ and $\mathrm{RuCl}_{3} \cdot \mathrm{H}_{2} \mathrm{O}$ at molar ratio $\mathrm{M}: \mathrm{L}: \mathrm{OH}^{-}=2: 4: 1$ for $\left[\mathrm{Pt}(\mathrm{L} 1)_{2}\left(\mathrm{H}_{2} \mathrm{O}\right)_{2}\left(\mathrm{OH}^{-}\right)_{2}\right]$, $\left[\mathrm{Ru}(\mathrm{L} 1)_{3}\left(\mathrm{H}_{2} \mathrm{O}\right)_{3}\right], \quad\left[\mathrm{Ru}(\mathrm{L} 2)_{3}\left(\mathrm{H}_{2} \mathrm{O}\right)_{3}\right]$ and 1:2:3 for $\left[\mathrm{Pt}(\mathrm{L} 2)_{2}\left(\mathrm{H}_{2} \mathrm{O}\right)_{2}\left(\mathrm{OH}^{-}\right)_{2}\right]$ were studied. Neutral complexes were synthesized and isolated as precipitates. The $\left[\mathrm{Pt}(\mathrm{L} 1)_{2}\left(\mathrm{H}_{2} \mathrm{O}\right)_{2}\left(\mathrm{OH}^{-}\right)_{2}\right]$ and $\left[\mathrm{Pt}(\mathrm{L} 2)_{2}\left(\mathrm{H}_{2} \mathrm{O}\right)_{2}\left(\mathrm{OH}^{-}\right)_{2}\right]$ complexes obtained have yellow colour and the $\left[\mathrm{Ru}(\mathrm{L} 1)_{3}\left(\mathrm{H}_{2} \mathrm{O}\right)_{3}\right]$ and $\left[\mathrm{Ru}(\mathrm{L} 2)_{3}\left(\mathrm{H}_{2} \mathrm{O}\right)_{3}\right]$ complexes have brown or black colour, respectively. All complexes were investigated by elemental analysis, UV-Vis and IR spectroscopy. Elemental analyses data was found to be in good agreement $(+0.5 \%)$ with the calculated values.

It was found that the molar ratio metal:ligand is $1: 2$ for $\quad\left[\mathrm{Pt}(\mathrm{L} 1)_{2}\left(\mathrm{H}_{2} \mathrm{O}\right)_{2}\left(\mathrm{OH}^{-}\right)_{2}\right], \quad\left[\mathrm{Pt}(\mathrm{L} 2)_{2}\left(\mathrm{H}_{2} \mathrm{O}\right)_{2}\right.$ $\left.\left(\mathrm{OH}^{-}\right)_{2}\right]$ and $1: 3$ for $\left[\mathrm{Ru}(\mathrm{L} 1)_{3}\left(\mathrm{H}_{2} \mathrm{O}\right)_{3}\right]$, $\left[\mathrm{Ru}(\mathrm{L} 2)_{3}\left(\mathrm{H}_{2} \mathrm{O}\right)_{3}\right]$ and have two or three molecules water in platinum and ruthenium complexes, respectively. In the composition of the two platinum complexes have two $\mathrm{OH}^{-}$groups $\left.[\mathrm{PtL} 1)_{2}\left(\mathrm{H}_{2} \mathrm{O}\right)_{2}\left(\mathrm{OH}^{-}\right)_{2}\right]$ and $\left[\mathrm{Pt}(\mathrm{L} 2)_{2}\left(\mathrm{H}_{2} \mathrm{O}\right)_{2}\left(\mathrm{OH}^{-}\right)_{2}\right]$. The composition of the $\mathrm{Ru}(\mathrm{III})$ complexes is $\left.[\mathrm{RuL} 1)_{3}\left(\mathrm{H}_{2} \mathrm{O}\right)_{3}\right]$ and $\left[\mathrm{Ru}(\mathrm{L} 2)_{3}\left(\mathrm{H}_{2} \mathrm{O}\right)_{3}\right]$. All UV-Vis spectra were registered in DMSO. Maxima in the UV spectra of the free ligands HL1 and HL2 were observed at $\lambda_{\max }=215,222,224,231,275 \mathrm{~nm}$ and 216, 225, 275, $300 \mathrm{~nm}$, respectively. Maxima in the electronic spectra of $\left[\mathrm{Pt}(\mathrm{L} 1)_{2}\left(\mathrm{H}_{2} \mathrm{O}\right)_{2}\left(\mathrm{OH}^{-}\right)_{2}\right]$ and $\left[\mathrm{Pt}(\mathrm{L} 2)_{2}\left(\mathrm{H}_{2} \mathrm{O}\right)_{2}\left(\mathrm{OH}^{-}\right)_{2}\right]$ complexes were observed at 223, 236, 276, $300 \mathrm{~nm}$ and 220, 231, $275 \mathrm{~nm}$, respectively. Maxima in the electronic spectra of $\left[\mathrm{Ru}(\mathrm{L} 1)_{3}\left(\mathrm{H}_{2} \mathrm{O}\right)_{3}\right]$ and $\left[\mathrm{Ru}(\mathrm{L} 2)_{3}\left(\mathrm{H}_{2} \mathrm{O}\right)_{3}\right]$ complexes were observed at 224, 273, 276, 285, 290 and 303 $\mathrm{nm}$, respectively. We performed preliminary UV analysis of the spectra of the ligands in dimethyl sulfoxide at room temperature. The spectrum of the ligand $\mathrm{HL1}$ is almost identical to the spectrum of the $\left[\mathrm{Pt}(\mathrm{L1})_{2}\left(\mathrm{H}_{2} \mathrm{O}\right)_{2}\left(\mathrm{OH}^{-}\right)_{2}\right]$. They show a small band at about $300 \mathrm{~nm}$ which could be assigned to the $\mathrm{n}_{\mathrm{O}} \rightarrow \pi^{*}$ electron transition in the ligand. The main absorption maximum of the spectra is due to the $\pi \rightarrow \pi^{*}$ electron transition in the ligand again. The $\mathrm{d}-\mathrm{d}$ band, if available, is included in the broad experimental band and it is shaded by the spectrum of the ligand.

In the $\left[\mathrm{Ru}(\mathrm{L} 1)_{3}\left(\mathrm{H}_{2} \mathrm{O}\right)_{3}\right]$ complex the main absorption band is similar to this of the ligand HL1. It corresponds to an electron transition $\pi \rightarrow \pi^{*}$ in the ligand. The spectrum of the complex is rather asymmetric and shows no shoulders of the band from the side of the larger wavelengths. Perhaps the shoulders of the band of HL1 come from the $\mathrm{n}_{\mathrm{N}} \rightarrow \pi^{*}$ electron transitions in the ligand. They disappear when the ligand HL1 forms complexes with ruthenium.

The smaller band at about $300 \mathrm{~nm}$ of ligand HL2, as compared to HL1, is due to the $\mathrm{n}_{\mathrm{O}} \rightarrow \pi^{*}$ electron transition of the only one oxygen atom available in this compound. In the $\left[\mathrm{Ru}(\mathrm{L} 2)_{3}\left(\mathrm{H}_{2} \mathrm{O}\right)_{3}\right]$ complex new shoulders appear from the side of the larger wavelengths. They are at about $285 \mathrm{~nm}, 290$ $\mathrm{nm}$, and $303 \mathrm{~nm}$. An octahedral geometry is tentatively presumed for all the metal complexes. Similar bands were also observed for the Pt(IV) complexes with 1,10-phenanthroline and 2,2'bipyridine and diaminocyclohexane as ligands. ${ }^{41}$ Similar bands have been also observed in other low-spin octahedral complexes of $\mathrm{Ru}^{\text {II }} /$ III and $\mathrm{Os}^{\mathrm{II} / \mathrm{III}} \cdot 42$

In order to evaluate the mode of coordination of the ligand to the metal ions, the IR spectra of the pure ligands, as well as of their metal complexes were recorded. The presence of two amide and one thioamide groups renders four donor atoms for coordination to the metal center: two O-atoms from carbonyl groups and two $\mathrm{N}$-atoms from amino groups (HL1) or one O-atom from carbonyl group, one S-atom from thiocarbonyl group and two N-atoms from amino groups (HL2). More complicated are the analyses of the IR spectra of the complexes where water molecules are present in the composition of the complexes. Selected vibrational frequencies observed in the IR spectra of the complexes were compared with those of the free ligands are presented in Table 1 .

In the IR spectrum of the free ligand HL1 bands at $3361 \mathrm{~cm}^{-1}$ and $3192 \mathrm{~cm}^{-1}$ were observed and referred to the stretching vibrations of the two $\mathrm{N}-\mathrm{H}$ groups of the hydantoin ring (see Table 1). In the IR spectra of the $\left[\mathrm{Pt}(\mathrm{L} 1)_{2}\left(\mathrm{H}_{2} \mathrm{O}\right)_{2}\left(\mathrm{OH}^{-}\right)_{2}\right]$ and $\left[\mathrm{Ru}(\mathrm{L} 1)_{3}\left(\mathrm{H}_{2} \mathrm{O}\right)_{3}\right]$ complexes the same bands were observed at 3241 and 3190; 3241 and $3191 \mathrm{~cm}^{-1}$, respectively. One of the two bands was shifted to the lower frequencies as compared to the free ligand spectrum (about $120 \mathrm{~cm}^{-1}$ ). The second band was not changed. In the spectrum of the free ligand HL1, the bands at $1776 \mathrm{~cm}^{-1}$ and 1718 $\mathrm{cm}^{-1}$ could be assigned to stretching vibration of $\mathrm{C}=\mathrm{O}$ group of the hydantoin ring. The bands resulting from the vibration of the $\mathrm{C}=\mathrm{O}$ groups in the IR spectra of $\left[\mathrm{Pt}(\mathrm{L} 1)_{2}\left(\mathrm{H}_{2} \mathrm{O}\right)_{2}\left(\mathrm{OH}^{-}\right)_{2}\right]$ and $\left[\mathrm{Ru}(\mathrm{L} 1)_{3}\left(\mathrm{H}_{2} \mathrm{O}\right)_{3}\right]$ complexes were not changed $\left(1776\right.$ and $1720 \mathrm{~cm}^{-1}$; 1776 and $1723 \mathrm{~cm}^{-1}$, respectively). This fact showed that the two carbonyl groups of the ligand hydantoin ring did not participate in the coordination with the metal ion. 
Table 1

Selected IR bands $\left(\mathrm{cm}^{-1}\right)$ in $\mathrm{KBr}$ for the free ligands, HL1 and HL2 and their Pt(IV) and Ru(III) complexes.

The band intensity is designated as vs, s, $\mathrm{m}$, w representing very strong, strong, medium, weak; sh = shoulder, br = broad

\begin{tabular}{|c|c|c|c|c|c|c|}
\hline assignments & HL1 & $\begin{array}{c}{\left[\mathrm{Pt}(\mathrm{L1})_{2}\left(\mathrm{H}_{2} \mathrm{O}\right)_{2}\right.} \\
\left.\left(\mathrm{OH}^{-}\right)_{2}\right]\end{array}$ & $\begin{array}{c}{\left[\mathrm{Ru}(\mathrm{L1})_{3}\right.} \\
\left.\left(\mathrm{H}_{2} \mathrm{O}\right)_{3}\right]\end{array}$ & HL2 & $\begin{array}{c}{\left[\mathbf{P t}(\mathbf{L 2})_{2}\left(\mathbf{H}_{\mathbf{2}} \mathbf{O}\right)_{2}\right.} \\
\left.\left(\mathrm{OH}^{-}\right)_{2}\right]\end{array}$ & {$\left[\mathrm{Ru}(\mathrm{L2})_{3}\left(\mathrm{H}_{2} \mathrm{O}\right)_{3}\right]$} \\
\hline v OH & - & ca. 3400 br & ca. $3378 \mathrm{br}$ & - & ca. 3387 br & ca. 3402 br \\
\hline$v^{3} \mathrm{NH}$ & $3361 \mathrm{~s}$ & $3241 \mathrm{~m}$ & $3241 \mathrm{~s}$ & $3250 \mathrm{~m}$ & $3300 \mathrm{~m}$ & $3370 \mathrm{~m}$ \\
\hline$v^{1} \mathrm{NH}$ & $3192 \mathrm{~s}$ & $3190 \mathrm{~s}$ & $3191 \mathrm{~s}$ & $3161 \mathrm{~m}$ & $3160 \mathrm{~m}$ & $3159 \mathrm{sh}$ \\
\hline v C-H & $\begin{array}{l}3074 \mathrm{~m} \\
3008 \mathrm{w}\end{array}$ & $3045 \mathrm{~m}$ & $3049 \mathrm{~m}$ & ca. $3070 \mathrm{sh}$ & $3058 \mathrm{~m}$ & $3100 \mathrm{w}$ \\
\hline$v^{2} \mathrm{C}=\mathrm{O}$ & 1776 vs & 1776 vs & 1776 vs & - & - & - \\
\hline$v^{4} \mathrm{C}=\mathrm{O}$ & $1718 \mathrm{vs}$ & 1720 vs & 1723 vs & 1730 vs & $1731 \mathrm{~s}$ & $1731 \mathrm{~s}$ \\
\hline$v^{2} \mathbf{C}=S$ & - & - & - & $1531 \mathrm{~s}$ & $1531 \mathrm{~s}$ & $1530 \mathrm{~s}$ \\
\hline
\end{tabular}

Table 2

Antimicrobial activity of the free ligands $\mathbf{H L 1}$ and $\mathbf{H L 2}$ and their $\left[\mathrm{Pt}(\mathrm{L} 1)_{2}\left(\mathrm{H}_{2} \mathrm{O}\right)_{2}\left(\mathrm{OH}^{-}\right)_{2}\right]$ and $\left[\mathrm{Ru}(\mathrm{L} 1)_{3}\left(\mathrm{H}_{2} \mathrm{O}\right)_{3}\right]$ complexes

\begin{tabular}{c|l|c|c|c}
\hline \multirow{2}{*}{ № } & \multicolumn{2}{|c|}{ Test microorganism } & \multicolumn{2}{c}{ Inhibition zone, mm } \\
\cline { 3 - 4 } & & $\mathrm{HL1}$ & {$\left[\mathrm{Pt}(\mathrm{L} 1)_{2}\left(\mathrm{H}_{2} \mathrm{O}\right)_{2}\left(\mathrm{OH}^{-}\right)_{2}\right]$} & {$\left[\mathrm{Ru}(\mathrm{L} 1)_{3}\left(\mathrm{H}_{2} \mathrm{O}\right)_{3}\right]$} \\
\hline 1 & Escherichia coli ATCC 8739 & - & 15 & - \\
\hline 2 & Bacillus licheniformis ATCC 6633 & - & 16 & - \\
\hline 3 & $\begin{array}{l}\text { Staphylococcus aureus } \\
\text { ATCC 6538 }\end{array}$ & 10 & 14 & - \\
\hline 4 & $\begin{array}{l}\text { Sacharomyces serevisiae } \\
\text { ATCC 9763 }\end{array}$ & - & - & - \\
\hline 5 & $\begin{array}{l}\text { Candida albicans } \\
\text { ATCC 10231 }\end{array}$ & - & - & - \\
\hline
\end{tabular}

Well diameter: $6 \mathrm{~mm}$

In the IR spectrum of the free ligand HL2 bands at $3250 \mathrm{~cm}^{-1}$ and $3161 \mathrm{~cm}^{-1}$ were observed, which we referred assigned of $\mathrm{N}-\mathrm{H}$ groups of the hydantoin ring. In the spectra of the $\left[\mathrm{Pt}(\mathrm{L} 2)_{2}\left(\mathrm{H}_{2} \mathrm{O}\right)_{2}\left(\mathrm{OH}^{-}\right)_{2}\right]$ and $\left[\mathrm{Ru}(\mathrm{L} 2)_{3}\left(\mathrm{H}_{2} \mathrm{O}\right)_{3}\right]$ complexes the same bands were observed at 3300 , $3160 \mathrm{~cm}^{-1}$ and 3370 and $3159 \mathrm{~cm}^{-1}$, respectively. One of the two bands was shifted to the higher frequencies as compared to the free ligand spectrum (about 50 and $120 \mathrm{~cm}^{-1}$, respectively). The second band was not changed. In the IR spectrum of the $\left[\mathrm{Pt}(\mathrm{L} 2)_{2}\left(\mathrm{H}_{2} \mathrm{O}\right)_{2}\left(\mathrm{OH}^{-}\right)_{2}\right]$ the broad band at $3387 \mathrm{~cm}^{-1}$ was assigned to the hydroxy groups attached to the coordination center. In the spectrum of the free ligand HL2 the bands at 1730 $\mathrm{cm}^{-1}$ and $1531 \mathrm{~cm}^{-1}$ could be assigned to oscillation stretching vibrations of $\mathrm{C}^{4}=\mathrm{O}$ and $\mathrm{C}^{2}=\mathrm{S}$ groups of the hydantoin ring. The bands resulting from the oscillation of the $\mathrm{C}^{4}=\mathrm{O}$ and $\mathrm{C}^{2}=\mathrm{S}$ groups in the IR spectra of $\left[\mathrm{Pt}(\mathrm{L} 2)_{2}\left(\mathrm{H}_{2} \mathrm{O}\right)_{2}\left(\mathrm{OH}^{-}\right)_{2}\right]$ and $\left[\mathrm{Ru}(\mathrm{L} 2)_{3}\left(\mathrm{H}_{2} \mathrm{O}\right)_{3}\right]$ complexes were not changed (1731 and $1531 \mathrm{~cm}^{-1} ; 1731$ and $1530 \mathrm{~cm}^{-1}$, respestively). This fact showed that the carbonyl and thiocarbonyl groups of the ligand did not participate in the coordination.

It was not possible to measure Raman spectra of the complexes - the sample burned even at 1
$\mathrm{mW}$ laser power. Only the Raman spectra of the free ligands HL1 and HL2 were measured and cited in our previous paper. ${ }^{29}$ The two vibrational $\left(\mathrm{N}^{1}-\mathrm{H}\right)$ and $\left(\mathrm{N}^{3}-\mathrm{H}\right)$ stretching modes did not appear in the Raman spectra of (9'-fluorene)-spiro-5hydantoin (HL1) and (9'-fluorene)-spiro-5-(2thiohydantoin) (HL2). In the IR spectrum of HL1 the bands at $1776 \mathrm{~cm}^{-1}$ and $1718 \mathrm{~cm}^{-1}$ can be attributed to stretching vibrations of $\mathrm{C}^{4}=\mathrm{O}$ and $\mathrm{C}^{2}=\mathrm{O}$ groups of the hydantoin ring. In the Raman spectrum of HL1 the same bands appears at 1777 $\mathrm{cm}^{-1}$ and $1720 \mathrm{~cm}^{-1}$. Several bands in the Raman spectrum $\left(3073,3041,3012 \mathrm{~cm}^{-1}\right)$ and in the IR spectrum $\left(3074,3008 \mathrm{~cm}^{-1}\right)$ come for stretching vibrations of $\mathrm{CH}$ in fluorene moiety. In the IR spectrum of HL2 the bands at $1730 \mathrm{~cm}^{-1}$ and 1530 $\mathrm{cm}^{-1}$ can be attributed to stretching vibrations of $\mathrm{C}^{4}=\mathrm{O}$ and $\mathrm{C}^{2}=\mathrm{S}$ groups of the hydantoin ring. In the Raman spectrum of HL2 the band of $\mathrm{C}^{4}=\mathrm{O}$ appears at $1728 \mathrm{~cm}^{-1}$ and band of $\mathrm{C}^{2}=\mathrm{S}$ group missed. Several bands in the Raman spectrum (3067, 3050, $3012 \mathrm{~cm}^{-1}$ ) were for stretching vibrations of $\mathrm{CH}$ in fluorene moiety.

The chemical structure of HL1 and HL2 was established through ${ }^{1} \mathrm{H}$ and ${ }^{13} \mathrm{C}$ NMR spectroscopy. The ${ }^{1} \mathrm{H}$ NMR spectra of HL1, HL2 showed two broad signals at 8.0-12.0 ppm characteristic of $\mathrm{NH}$ 
protons. The ${ }^{13} \mathrm{C}$ NMR spectrum of the (9'fluorene)-spiro-5-hydantoin) (HL1) and of (9'fluorene)-spiro-5-(2-thiohydantoin) (HL2) showed 9 signals: 6 pairs of atoms were magnetically equivalent. The two signals with the highest chemical shift in ${ }^{13} \mathrm{C}$ NMR spectrum, 174.6 and $183.5 \mathrm{ppm}, 158.1$ and $174.7 \mathrm{ppm}$ were for the carbonyl groups $\left(\mathrm{C}^{4}=\mathrm{O}\right)$ and $\left(\mathrm{C}^{2}=\mathrm{O}\right)$, respectively. The signals at 72.8 (HL1) and 74.8 (HL2) ppm ppm were for the spiro-carbon atom, respectively.

The most probable structures of the two platinum complexes were suggested with two ligand molecules coordinated in a monodentate fashion (probably with $\mathrm{N}^{3}$-atom) and with two water molecules and two $\mathrm{OH}^{-}$groups coordinated to the metal centre (octahedral geometry for metal ion). For the two ruthenium complexes octahedral geometry were suggested with three ligand molecules coordinated in a monodentate mode and with three water molecules coordinated to the metal ion.

The antimicrobial activity of the products obtained was determined against Gram-positive bacteria Staphylococcus aureus ATCC 6538 and Bacillus licheniformis ATCC 6633, Gram-negative bacterium Escherichia coli ATCC 8739 and the yeasts Candida albicans ATCC 10231 and Sacharomyces serevisiae ATCC 9763. The results obtained from these analyses are listed in Table 2 . The compounds presented in this study: (9'fluorene)-spiro-5-(2-thiohydantoin) (HL2) and its $\left[\mathrm{Pt}(\mathrm{L} 2)_{2}\left(\mathrm{H}_{2} \mathrm{O}\right)_{2}\left(\mathrm{OH}^{-}\right)_{2}\right]$ and $\left[\mathrm{Ru}(\mathrm{L} 2)_{3}\left(\mathrm{H}_{2} \mathrm{O}\right)_{3}\right]$ complexes do not possess antimicrobial activity against the tested bacteria and yeasts.

In contrast, (9'-fluorene)-spiro-5-hydantoin (HL1) exhibits a week bacteriostatic effect against Gram-positive bacteria $S$. aureus and the absence of such action of the tested Gram-negative bacterium and yeasts. MIC of HL1 was $3,8 \mathrm{mg} / \mathrm{mL}$. The antimicrobial tests of $\left[\mathrm{Pt}(\mathrm{L1})_{2}\left(\mathrm{H}_{2} \mathrm{O}\right)_{2}\left(\mathrm{OH}^{-}\right)_{2}\right]$ complex showed a pronounced antimicrobial activity against the Gram-positive and Gram-negative bacteria. There was no activity towards Candida albicans and Sacharomyces serevisiae. MIC of $\left[\mathrm{Pt}(\mathrm{L} 1)_{2}\left(\mathrm{H}_{2} \mathrm{O}\right)_{2}\left(\mathrm{OH}^{-}\right)_{2}\right]$ for $E$. coli was $2.2 \mathrm{mg} / \mathrm{mL}, B$. licheniformis - $1.8 \mathrm{mg} / \mathrm{mL}$, S. aureus $-2,6 \mathrm{mg} / \mathrm{mL}$.

For comparison, the biological potential between similar compounds show that the $\mathrm{Ru}(\mathrm{III})$ complex with 4'-bromo-(9'-fluorene)-spiro-5-(2,4dithiohydantoin) has a moderate cytotoxic activity on the human retinoblastoma cell line WERI$\mathrm{Rb} 1 .{ }^{43}$ We have found that prolonged incubation periods do not influence cell viability. In contrast, the $\mathrm{Pt}(\mathrm{II})$ complex with the same ligand does not perturb cell proliferation at all. We have previously shown that the 4'-bromo-(9'-fluorene)-spiro-5-(2,4dithiohydantoin) significantly reduces the number of cells (WERI-Rb1) in a time-dependent manner. ${ }^{27}$ Our results published earlier revealed that L1, Pt(II)L1 and Pt(II)L2 had a cytotoxic effect on the cell line WERI-Rb1. ${ }^{29}$ We found that prolonged incubation periods influenced dramatically cell viability. It should be noted that the two Pt(II) complexes showed significant effects on cancer cell growth compared to their ligands. The results from the cytotoxicity assay showed that $\mathrm{Pt}(\mathrm{II})$ complexes reduced the number of cells by around $20 \%$ after $24 \mathrm{~h}$ and led to complete inhibition of cell viability at $72 \mathrm{~h}$ of treatment. In contrast, the ligand HL2, did not show any inhibitory effect within the tested concentration, while HL1 reduced the amount of cancer cells by around $20 \%$ after $24 \mathrm{~h}$ only. ${ }^{29}$

\section{CONCLUSIONS}

Four new metal complexes of (9'-fluorene)spiro-5-hydantoin (HL1) and (9'-fluorene)-spiro-5(2-thiohydantoin) (HL2) were obtained with Pt(IV) and $\mathrm{Ru}(\mathrm{III})$. They were characterized by elemental analysis, UV-Vis and vibrational IR spectroscopy. (9'-fluorene)-spiro-5-hydantoin (HL1) and (9'Fluorene)-spiro-5-(2-thiohydantoin) (HL2) were studied by elemental analysis, IR, Raman and ${ }^{1} \mathrm{H}$, ${ }^{13} \mathrm{C}$ NMR spectroscopy. Based on the experimental data, the most probable structures for the $\left[\mathrm{Pt}(\mathrm{L} 1)_{2}\left(\mathrm{H}_{2} \mathrm{O}\right)_{2}\left(\mathrm{OH}^{-}\right)_{2}\right], \quad\left[\mathrm{Pt}(\mathrm{L} 2)_{2}\left(\mathrm{H}_{2} \mathrm{O}\right)_{2}\left(\mathrm{OH}^{-}\right)_{2}\right]$, $\left[\mathrm{Ru}(\mathrm{L} 1)_{3}\left(\mathrm{H}_{2} \mathrm{O}\right)_{3}\right]$ and $\left[\mathrm{Ru}(\mathrm{L} 2)_{3}\left(\mathrm{H}_{2} \mathrm{O}\right)_{3}\right]$ complexes were suggested with one deprotonated $\mathrm{NH}$ group of ligand HL1 or HL2. For the two platinum complexes octahedral geometry were suggested with two ligand molecules coordinated in a monodentate fashion (N3) and with two water molecules and two $\mathrm{OH}^{-}$groups coordinated to the metal center. For the ruthenium complexes the same geometry were suggested with three ligand molecules and three water molecules coordinated to the metal ion. The results for (9'-fluorene)spiro-5-(2-thiohydantoin) (HL2) and its metal complexes showed that they not have a potential as antimicrobial agents against the tested Gram positive, Gram-negative bacteria and the yeasts. The antimicrobial tests of (9'-fluorene)-spiro-5hydantoin (HL1) showed week bacteriostatic effect against Gram-positive bacteria $S$. aureus. The results for $\left[\mathrm{Pt}(\mathrm{L} 1)_{2}\left(\mathrm{H}_{2} \mathrm{O}\right)_{2}\left(\mathrm{OH}^{-}\right)_{2}\right]$ complex showed a good antimicrobial activity against the Gram- 
positive and Gram-negative bacteria and the absence of such effect of the yeasts.

Acknowledgements. This work was supported by the National Science Fund of Bulgaria, under Grants DFNI BO1/0014, DMU 02/11 and project FP17-HF-013.

\section{REFERENCES}

1. D. A. Williams and T. L. Lemke, "Foye's principles of medicinal chemistry", Philadelphia, Lippincott Williams \& Wilkins, $6^{\text {th }}$ edition by T. L. Lemke, D. A. Williams, 2007.

2. A. Kleemann, J. Engel, B. Kutscher and D. Reichert, "Pharmaceutical Substances: Synthesis, Patents, Applications of the most relevant APIs", Vol. 2, Thieme: Stuttgart, New York, $5^{\text {th }}$ Edition, completely revised, 2001.

3. A. Takahashi, H. Matsuoka, Y. Ozawa and Y. Uda, J. Agric. Food Chem., 1998, 46, 5037-5042.

4. A. Takahashi, H. Matsuoka and Y. Uda, Environ. Mutagen res., 2004, 26, 1-8.

5. J. Marton, J. Enisz, S. Hosztafi and T. Tímár, J. Agric. Food Chem., 1993, 41, 148-152.

6. M. Blanc, M. Cussac, A. Boucherle and G. Leclerc, Eur. J. Med. Chem., 1992, 27, 267-275.

7. V. Chazeau, M. Cussac and A. Boucherle, Eur. J. Med Chem., 1992, 27, 615-625.

8. M. Blanc, M. Cussac, A. Boucherle and G. Leclerc, Eur. J. Med. Chem., 1992, 27, 839-843.

9. E. Naydenova, M. Pencheva, J. Popova, N. Stoyanov, M. Lazarova and B. Aleksiev, Il Farmaco, 2002, 57, 189-194.

10. C. S. Ananda Kumar, C. V. Kavitha, K. Vinaya, Benaka S. B. Prasad, N. R. Thimmegowda, S. Chandrappa, S. C. Raghavan and K. S. Rangappa, Invest New Drugs, 2009, 27, 327-337.

11. B. Rosenberg, L. VanCamp and T. Krigas, Nature, 1965, 205, 698-9.

12. M. D. Hall and T. W. Hambley, Coord Chem Rev., 2002, $232,49-67$

13. O. Nováková, O. Vrána, V. I. Kiseleva and V. Brabec, Eur. J. Biochem. 1995, 228, 616-624.

14. L. R. Kelland, B. A. Murrer, G. Abel, C. M. Giandomenico, P. Mistry and K. R. Harrap Cancer Res., 1992, 52, 822-828.

15. F. P. Dwyer, E. C. Gyarfas, W. P. Rogers and J. H. Koch, Nature, 1952, 170, 190-191.

16. M. J. Clarke, "Oncological implications of the chemistry of ruthenium", in Sigel H (Ed.), "Metal Ions in Biological Systems", Marcel Dekker, 1980, p. 231-283.

17. M. J. Clarke, Coord Chem Rev., 2003, 236, 209-233.

18. C. G. Hartinger, S. Zorbas-Seifried, M. A. Jakupec, B. Kynast, H .Zorbas, B. K. Keppler J. Inorg. Biochem., 2006, 100, 891-904.

19. I. Kostova, Curr. Med. Chem., 2006, 13, 1085-1107.

20. E. Alessio, G. Mestroni, A. Bergamo and G. Sava, Curr. Top. Med. Chem., 2004, 4, 1525-1535.

21. M. Galanski, V. B. Arion, M. A. Jakupec and B. K. Keppler, Curr. Pharm. Des., 2003, 9, 2078-2089.
22. N. Graf and S. J. Lippard, Adv Drug Deliv Rev., 2012, 64, 993-1004

23. M. Marinov, S. Minchev, N. Stoyanov, G. Ivanova, M. Spassova and V. Enchev, Croat. Chem. Acta, 2005, 78, 9-16.

24. B. Shivachev, R. Petrova, P. Marinova, N. Stoyanov, A. Ahmedova and M. Mitewa, Acta Crystallogr. C, 2006, 62, o211-0215.

25. A. Ahmedova, G. Pavlović, M. Marinov, N. Stoyanov, D. Šišak and M. Mitewa, J. Mol. Struct., 2009, 938, 165-173.

26. V. Enchev, N. Stoyanov, V. Mateva, J. Popova, M. Kashchieva, B. Aleksiev and M. Mitewa, Struct. Chem., 1999, 10, 381-385.

27. P. Marinova, M. Marinov, Y. Feodorova, M. Kazakova, D. Georgiev, E. Trendafilova, P. Penchev, V. Sarafian and N. Stoyanov, University of Ruse "A. Kanchev" Proceedings, Chemical technologies, 2013, 52, 33-37.

28. P. Marinova, M. Marinov, M. Kazakova, Y. Feodorova, D. Georgiev, V. Lekova, P. Penchev and N. Stoyanov, Compt. Rend. Acad. Bulg. Sci., 2014, 67, 513-518.

29. P. Marinova, M. Marinov, M. Kazakova, Y. Feodorova, P. Penchev, V. Sarafian and N. Stoyanov, Biotechnol. Biotec. Eq., 2014, 28, 316-321.

30. A. Ahmedova, P. Marinova, M. Marinov and N. Stoyanov, J. Mol. Struct., 2016, 1108, 602-610.

31. A. Ahmedova, P. Marinova, K. Paradowska, M. Marinov and M. Mitewa, J. Mol. Struct., 2008, 892, 13-19.

32. A. Ahmedova, P. Marinova, K. Paradowska, N. Stoyanov, I. Wawer and M. Mitewa, Inorg. Chim. Acta, 2010, 363, 3919-3925.

33. M. Marinov, P. Marinova, N. Stoyanov, N. Markova and V. Enchev, Acta Chim. Slov. 2014, 61, 420-424.

34. P. Marinova, M. Marinov, M. Kazakova, Y. Feodorova, A. Slavchev, D. Blazheva, D. Georgiev, P. Penchev, V. Sarafian and N. Stoyanov, Acta Chim. Slov., 2016, 63, 26-32.

35. L. I. Socea, G. Saramet, C. Draghici, B. Socea, V. D. Constantin and M. A. Radu-Popescu, J. Serb. Chem. Soc., 2015, 80, 1-11.

36. A. Bakalova, R. Buyukliev, G. Momekov and D. Ivanov, J. Chemical Tech. Metallurgy, 2013, 48, 631-636.

37. D. Kushev, E. Naydenova, J. Popova, L. Maneva, K. Grancharov and N. Spassovska, Z. Naturforsch. C, 2003, 58, 103-108.

38. H. T. Nagasawa, J. A. Elberling and F. N. Shirota, J. Med. Chem., 1973, 16, 823-826.

39. M. Marinov, P. Marinova and N. Stoyanov, Asian Chem. Lett., 2011, 15, 17-20.

40. C. Perez, M. Pauli and P. Bazevque, Acta Biol. Med. Exp., 1990, 15, 113-115.

41. X. Zhao, Y. Zhang, X. Hou, J. Shi, S. Shen and S. Huo, Transit Met Chem, 2017, 42, 219-228.

42. M. Srnec, J. Chalupský and L. Rulíšek, Collect. Czech. Chem. Commun., 2008, 73, 1231-1244.

43. P. E. Marinova, M. N. Marinov, M. H. Kazakova, Y. N. Feodorova, V. S. Sarafian, N. M. Stoyanov, Bulg. Chem. Commun., 2015, 47(Special issue A), 75-79. 
